Article

\title{
Synthesis and Characterization of N-Methyl Fatty Hydroxamic Acids from Ketapang Seed Oil Catalyzed by Lipase
}

\author{
Dedy Suhendra, Erin Ryantin Gunawan * and Hajidi Hajidi \\ Chemistry Department, Faculty of Mathematics and Natural Science, University of Mataram, Mataram 83125, \\ Indonesia; dedysuhendra@unram.ac.id (D.S.); jirdycr7@gmail.com (H.H.) \\ * Correspondence: erinryantin@unram.ac.id; Tel.: +62-813-3975-3767
}

Received: 27 September 2019; Accepted: 25 October 2019; Published: 29 October 2019

check for updates

\begin{abstract}
N-methyl fatty hydroxamic acid (N-MFHA), which is a derivative of hydroxamic acid (HA), was synthesized from ketapang seed oil (Terminalia catappa L.). In general, HAs have wide applications due to their chelating properties and biological activities. N-MFHAs were synthesized using immobilized lipase (Lipozyme TL IM) in biphasic medium which was the ketapang seed oil dissolved in hexane and N-methylhydroxylamine dissolved in water. The products were characterized through color testing and FT-IR spectroscopy after purification. Various factors affecting the enzyme activity investigated in the study included the effect of incubation time, the amount of lipase used, and the temperature. On the basis of the results, the optimum conditions for the synthesis of N-MFHA obtained are $25 \mathrm{~h}$ of incubation time, a temperature of $40{ }^{\circ} \mathrm{C}$, and a ratio of 1:100 for the amount of enzyme (g)/oil (g). At the optimum conditions of the reaction, $59.7 \%$ of the oils were converted to N-MFHA.
\end{abstract}

Keywords: ketapang seed oil; N-methylhydroxylamine; N-MFHA; Lipozyme TL IM

\section{Introduction}

According to [1], hydroxamic acid (HA), represented by the general formula, R-CO-NHOH, is a compound derived from oxoacid by replacing the $-\mathrm{OH}$ in it by $-\mathrm{NHOH}$, and its hydrocarbyl derivatives. The HAs are much weaker acids as compared with the corresponding carboxylic acids despite having identical carbon chains, however, they possess stronger abilities for selectively chelating metal ions [2]. As a metal binding group, HA are also widely used as a metalloenzyme inhibitor, including tyrosinase inhibitors [3], histone deacetylase inhibitors [4-7], and HIV-integrase inhibitors [8]. Additionally, they have a wide spectrum of biological activities, such as anticancer [9,10], antituberculosis [11,12], anti-hepatitis C virus [13], and antibacterial [14] properties. Furthermore, the acid complexes with other metal ions are widely used in analytical chemistry, such as a reagent for gravimetric and spectrometric metals determination [15], as a chemical sensor in determination of metal ions [16], and as a reagent for removal of Acid Red 88 from textile wastewater [17].

On the basis of a literature review, it is evident that many studies have been carried out involving the production of HA from various feedstocks, which are now available as commercial products, however, the long chain HA have not been commercially available. They are widely used as surfactants in the pharmaceutical and soap industries [18]. Long chain HA are synthesized using fatty acids or vegetable oils as feedstock, in the presence of some enzymes. Fatty hydroxamic acids (FHA), one of the derivatives of long chain HA, have been synthesized with the use of both edible and non-edible vegetable oils. The edible oils that have been used as a raw material for the synthesis of FHA are soybean oil [19] and palm oil [20]. Meanwhile, the non-edible oil that has been used for the synthesis of FHA is ketapang kernel oil [21]. 
For this research, our focus is the synthesis of another FHA derivative, N-methyl fatty hydroxamic acids (N-MFHA), in the presence of lipase as catalyst. The ketapang seeds contain about $55 \%$ to $60 \%$ oil, which are basically medium to long chain of fatty acids. According to Suhendra et al. (2018) [21], the fatty acids composition of these seeds include palmitic (35\% to $36 \%)$, palmitoleic $(0.3 \%$ to $0.5 \%)$, stearic ( $4 \%$ to $5 \%$ ), oleic ( $38 \%$ to $39 \%)$, linoleic (20\% to $21 \%)$, arachidonic $(0.5 \%$ to $0.6 \%)$, and others $(0.1 \%)$. In addition, the ketapang trees are widely distributed in Indonesia and are among the plants which bear fruits throughout the year. Their oil also has some characteristic physical-chemical properties. Hence, it has the potential to be used as feedstock for production of the long chain HA under study, N-MFHA.

\section{Results and Discussion}

\subsection{Identification of the Product}

The identification of the N-MFHA, as shown in Scheme 1, was achieved by observing the color changes in the reaction of the products with copper (II), iron (III), and vanadium (V) metal ions. The formation of colored complexes between these metal ions and hydroxamic groups is a typical reaction (Suhendra et al., 2005). Green, dark red and purple are the complex colors of copper(II)-N-MFHA, iron(III)-N-MFHA and vanadium(V)-N-MFHA ions.

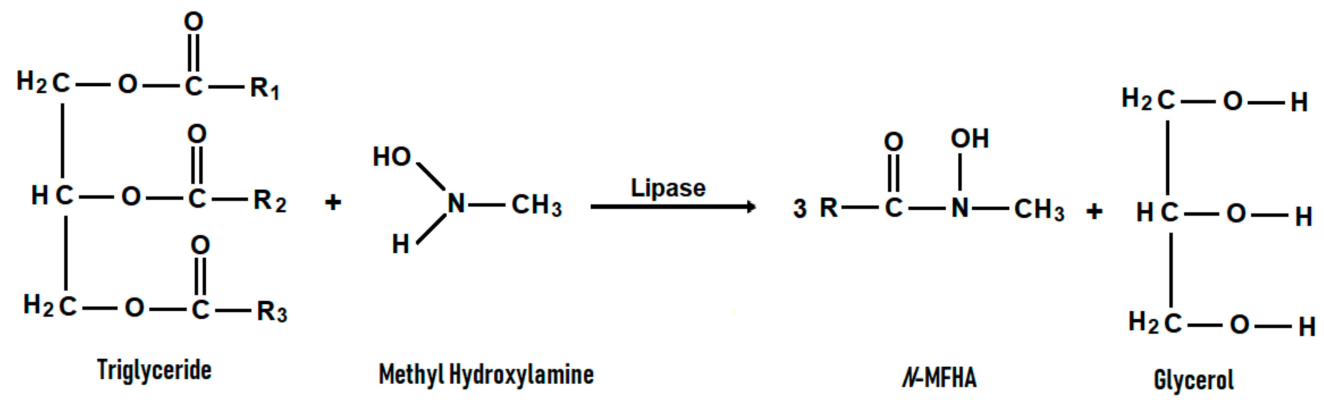

Scheme 1. The reaction of N-MFHA synthesis.

The FTIR spectrum of ketapang oil, as shown in Figure 1, has a typical absorption at 2950 to 2800 $\mathrm{cm}^{-1}$, which is C-H stretching from long chain alkyl. These C-H absorption bands are supported by peak at 1500 to $1450 \mathrm{~cm}^{-1}$ (C-H bonding) and the spectrum of product is a typical absorption band for hydroxamic acid groups, which peak at 3400 to $3200 \mathrm{~cm}^{-1}$. This is a typical absorption band for amide. The other absorption band at 1690 to $1630 \mathrm{~cm}^{-1}$ corresponds to the band for $\mathrm{C}=\mathrm{O}$ of amide.

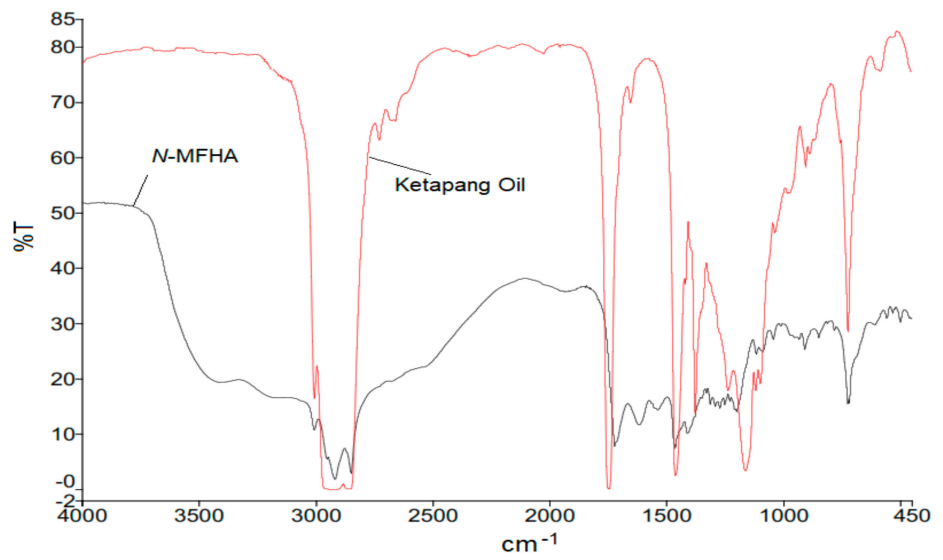

Figure 1. FTIR spectrum from ketapang oil and the products (N-MFHA).

The nitrogen content of the product, which was determined using the Kjeldahl method, was 3.46\%. This is an indication that there are $2.47 \mathrm{mmol}$ N-MFHA in every $1 \mathrm{~g}$ of the product, however, the 
analysis of the products with HPLC shows that N-MFHA is a mixture of 36\% palmityl-, $5 \%$ stearyl-, $30 \%$ oleyl-, and $29 \%$ linoleyl- $N$-methyl hydroxic acid.

\subsection{Optimization of the Reaction Conditions}

\subsubsection{Effect of Incubation Time}

Enzymes are biocatalysts produced by living organisms for the purpose of accelerating chemical reactions, by reducing activation energy, but remain unchanged at the end of the reactions. They are the most abundant group of proteins in living cells and when a protein is experiencing denaturation, they lose catalytic activity over time. Some enzymes usually lose a large number of their catalytic activity during the incubation period. Hence, the effect of incubation time is a good indicator for enzyme performance and reaction progress. It pinpoints the shortest and most adequate time necessary to obtain good yields and minimize expenses [20].

As shown in Figure 2, the production of N-MFHA increases with increasing incubation time, up to $25 \mathrm{~h}$. This is in line with the result of the study conducted by Salwanee et al. (2013) [22], who reported that the longer the incubation time, the more catalytic events had taken place at the active site, thereby resulting in higher amounts of N-MFHA. It is also evident from the figure that after $25 \mathrm{~h}$, the amount of N-MFHA produced began to decrease. This is due to the fact that the reaction catalyzed by the enzyme is reversible. The incubation time obtained from this study is faster than the results of Suhendra et al. (2005) [20], during the synthesis of fatty hydroxamic acids from palm oil, which was at $30 \mathrm{~h}$.

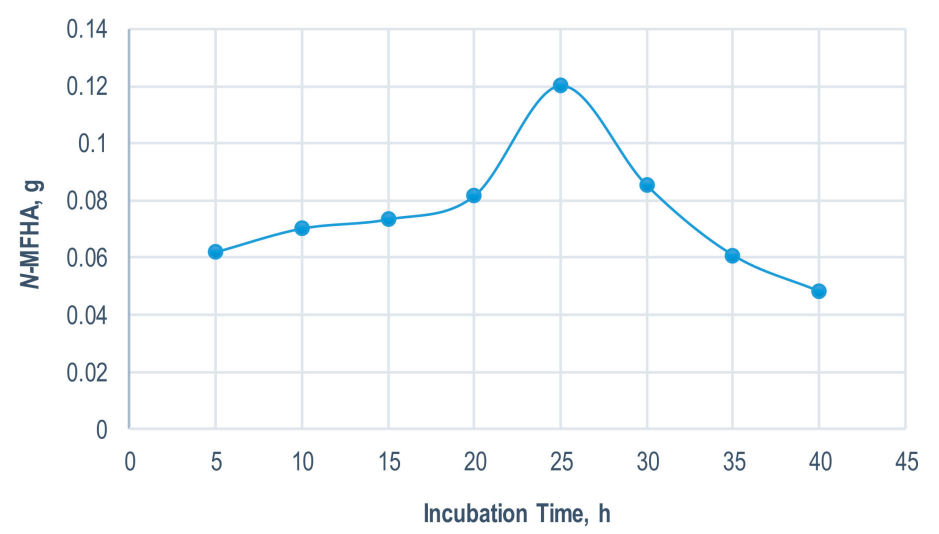

Figure 2. Effect of incubation time: $2 \mathrm{~g}$ of oil, $10 \mathrm{mmol}$ of $\mathrm{N}$-methylhydroxylamine, $15 \mathrm{~mL}$ of hexane, $0.02 \mathrm{~g}$ of Lipozyme TL IM, and $40^{\circ} \mathrm{C}$.

\subsubsection{Effect of Amount of Immobilized Lipase}

In terms of production cost, the substrate concentration must be as high as possible to get higher yields, however, the amount of enzyme in the reaction should be as low as possible in order to obtain maximum product yield per unit of enzyme.

Considering Figure 3, the maximum production of N-MFHA occurs at a fixed ketapang seed oil concentration $(0.12 \mathrm{~g} / \mathrm{mL})$, with the use of $0.02 \mathrm{~g}$ Lipozyme TL IM, after which the product yield is relatively constant. Increasing the amount of enzyme increases the rate of enzymatic reaction, until a limiting rate is reached, which is caused by more collisions between the enzyme and both the substrate and product molecules [21]. 


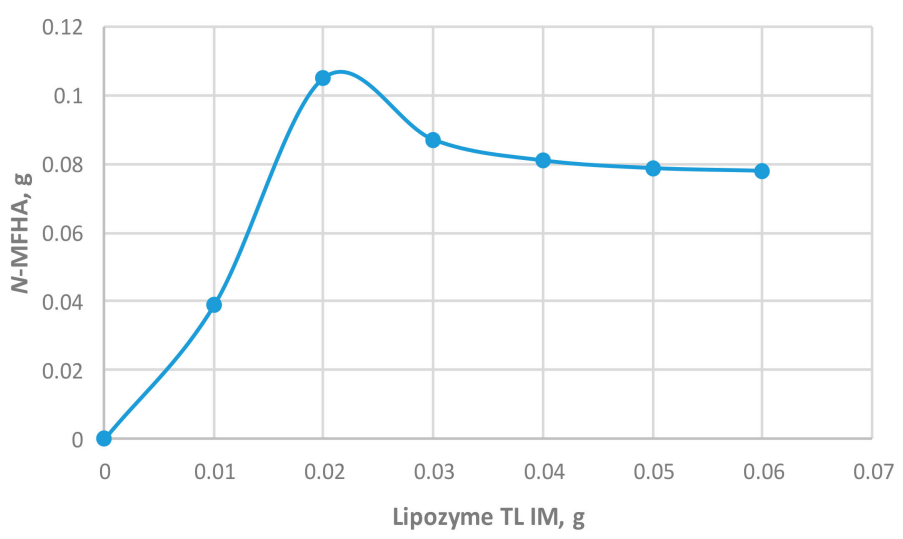

Figure 3. Effect of amount of enzyme: $2 \mathrm{~g}$ of oil, $10 \mathrm{mmol}$ of $\mathrm{N}$-methylhydroxylamine, $15 \mathrm{~mL}$ of hexane, and $25 \mathrm{~h}$ of incubation time.

\subsubsection{Effect of Temperature}

Generally, in all chemical reactions, an increase in temperature leads to an increase in the kinetic energy of the reacting molecules. Hence, there are more random collisions between the molecules per unit time, however, for enzymatic reactions, an increase in temperature also leads to an increase in the vibrational energy of the enzyme-substrate molecules.

As shown in Figure 4, the optimum temperature, at which the maximum reaction rate occurs, is $40{ }^{\circ} \mathrm{C}$. The figure also shows an increase in temperature to the optimum, $40{ }^{\circ} \mathrm{C}$, causing an increase in N-MFHA production, however, immediately after the optimum temperature, an increase in temperature causes a decrease in the production of N-MFHA. This is due to the fact that at the optimum temperature, the collision between the enzyme and substrate occurs very effectively, which causes the formation of an enzyme-substrate complex more easily. Additionally, according to [23], an increase in temperature increases the solubility of the substrate, thereby making available more substrates for the enzymatic reactions. Then, after the optimum temperature, the production of N-MFHA decreased quite sharply. This is due to the fact that at high temperatures, the active site of the enzyme changes shape, making it less complementary to the shape of the substrate, hence, its ability to catalyze is reduced. Finally, the enzyme is denatured and no longer functions [24].

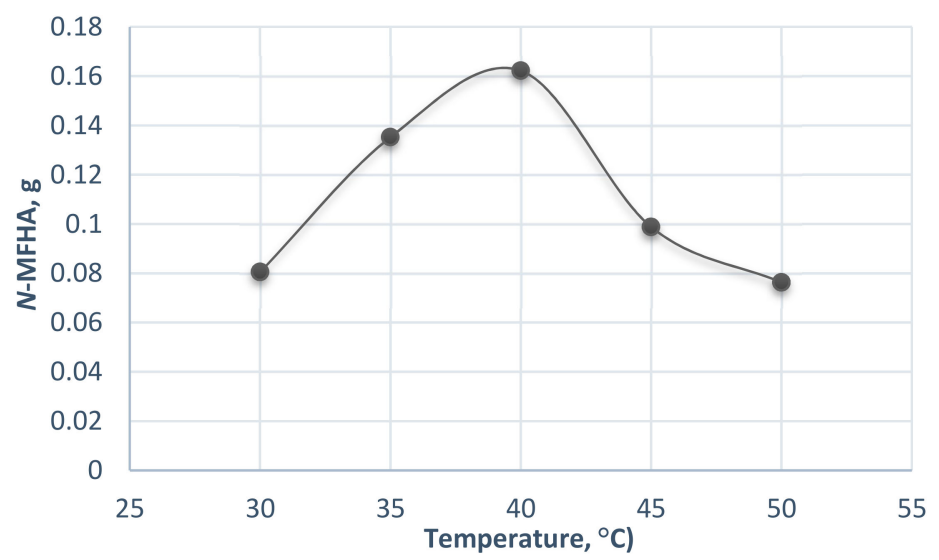

Figure 4. Effect of temperature: $2 \mathrm{~g}$ of oil, $10 \mathrm{mmol}$ of $\mathrm{N}$-methylhydroxylamine, $15 \mathrm{~mL}$ of hexane, $0.02 \mathrm{~g}$ of Lipozyme TL IM, and $25 \mathrm{~h}$ of incubation time.

\subsection{Synthesis Using the Optimum Reaction Conditions}

N-MFHA has been synthesized using the optimum conditions of the reaction, as presented in Table 1 . The reaction conditions were $20 \mathrm{~g}$ of oil, $100 \mathrm{mmol}$ of $\mathrm{N}$-methylhydroxylamine, $150 \mathrm{~mL}$ of hexane, $0.2 \mathrm{~g}$ of lipozyme TL IM, $25 \mathrm{~h}$ of incubation time, and $40{ }^{\circ} \mathrm{C}$. 
Table 1. Reaction parameters of synthesis of N-MFHA.

\begin{tabular}{ll}
\hline \multicolumn{1}{c}{ Parameters } & Condition \\
\hline Immobilized lipase & Lipozyme TL IM \\
Solvent & Hexane \\
Ratio of oil (g) to N-methylhydroxylamine (mmol) & $1: 5$ \\
Temperature & $40{ }^{\circ} \mathrm{C}$ \\
Incubation time & $25 \mathrm{~h}$ \\
Ratio of lipozyme TL IM (g) to oil $(\mathrm{g})$ & 0.01 \\
\hline
\end{tabular}

The percentage of N-MFHA formation using the optimum conditions of the reaction above was $59.7 \%$.

\section{Material and Methods}

\subsection{Material}

All the chemicals and reagents were purchased from commercial suppliers and used as received. The researchers ensured that they were all of analytical grade and they included: $N$-methylhydroxylamine hydrochloride (Tokyo Chemical Industry, TCI, Tokyo, Japan), sodium hydroxide, methanol, and hexane from (Merck, Darmstadt, Germany), and the immobilized lipase (Lipozyme) from (Novozymes, Bagsværd, Denmark).

\subsection{Extraction of Ketapang Seed Oil}

The extraction of oil from the ketapang seeds was carried out using the modified method developed by Suhendra et al. (2018) [21]. First, the seeds were mashed and about $10 \mathrm{~g}$ were put into the Soxhlet extraction thimble and extracted with $250 \mathrm{~mL}$ of $n$-hexane for $6 \mathrm{~h}$. Then, the extracts were purified by removing its solvent using a rotary evaporator at $40{ }^{\circ} \mathrm{C}$ and later the oil was passed into a chromatographic column containing silica gel, then eluted using $n$-hexane.

\subsection{Synthesis of N-MFHA}

The synthesis of N-MFHA from ketapang seed oil, in general, followed the modified procedures developed by Suhendra et al. (2018) [21]. This involved the addition of some ketapang oil with $15 \mathrm{~mL}$ of hexane in a $100 \mathrm{~mL}$ closed Erlenmeyer. Then, $\mathrm{N}$-methylhydroxylamine hydrochloride, neutralized using $6 \mathrm{M} \mathrm{NaOH}$, was added at a certain concentration. The mixture was incubated in a water shaker bath at a temperature of $30{ }^{\circ} \mathrm{C}$ to $40{ }^{\circ} \mathrm{C}$ with a shaking speed of $100 \mathrm{rpm}$. The N-MFHA formed in the hexane phase was separated from the water and Lipozyme TL IM phases. Then, the hexane phase was cooled to $<5{ }^{\circ} \mathrm{C}$ for five hours and the N-MFHA formed was filtered and washed using hexane to remove residual oil as well as other impurities. Finally, the N-MFHA was stored in a desiccator over phosphorus pentoxide.

\subsection{Characterization}

The qualitative analysis of the HA group was conducted using several modifications of the procedures developed by Suhendra et al. (2005) [20], mainly through color test and FTIR. Usually, a colored complex was formed whenever the methanolic solution of HA reacted with iron(III) or copper(II) ions. Then, the FTIR spectra of the products were recorded using a FTIR Spectrophotometer (Perkin Elmer FTIR-Frontier, Waltham, MA, USA). The quantitative analysis of the product was conducted by determining its nitrogen content using the Kjeldahl method. Additionally, the other quantitative analysis used high-performance liquid chromatography (HPLC, Waters, Milford, MA, USA). For HPLC, a Waters Model Breeze 1525 Preparative Gradient was also equipped with a Waters model 1525 binary pump, a Waters model 2489 UV/VIS detector, and a SunFire C18 $5 \mu \mathrm{m} 4.6 \times 150$ $\mathrm{mm}$ reversed-phase column. The analysis was carried out using acetonitrile as eluent at a flow rate of $1.0 \mathrm{~mL} /$ minute and the absorbance monitored at $213 \mathrm{~nm}$. 


\section{Conclusions}

This study investigated the synthesis of $N$-methyl fatty hydroxamic acids from ketapang seed oil using the lipase-active biocatalyst Lipozyme TL IM. Various factors affecting the enzyme activity were investigated including the effect of incubation time, amount of Lipozyme TL IM used, and temperature. On the basis of the results, the optimum conditions for the synthesis of N-MFHA obtained are 24 to $26 \mathrm{~h}$ of incubation time, a temperature of $40^{\circ} \mathrm{C}$, and a ratio of 1:100 for the amount of Lipozyme TL IM (g)/oil (g).

Author Contributions: Conceptualization, D.S. and E.R.G.; methodology, D.S.; software, E.R.G.; validation, D.S., E.R.G. and H.H.; formal analysis, E.R.G.; investigation, H.H.; resources, H.H.; data curation, H.H.; writing-original draft preparation, D.S.; writing-review and editing, E.R.G.; visualization, D.S.; supervision, D.S.; project administration, E.R.G.; funding acquisition, E.R.G.

Funding: This research work was financed through a grant from the Directorate General of Research and Development Strengthening, Ministry of Research Technology and Higher Education, Republic of Indonesia, with the agreement number: 065/SP2H/LT/DRPM/2018.

Conflicts of Interest: The authors declare no conflict of interest. The funders had no role in the design of the study; in the collection, analyses, or interpretation of data; in the writing of the manuscript, or in the decision to publish the results.

\section{References}

1. Kakkar, R. Theoretical Studies on Hydroxamic Acids. In Hydroxamic Acids: A Unique Family of Chemicals with Multiple Biological Activities; Gupta, S.P., Ed.; Springer Heidelberg: New York, NY, USA, 2013; pp. $19-53$.

2. Xu, H.; Zhong, H.; Tang, Q.; Wang, S.; Zhao, G.; Liu, G. A novel collector 2-ethyl-2-hexenoic hydroxamic acid: Flotation performance and adsorption mechanism to ilmenite. Appl. Surf. Sci. 2015, 353, 882-889. [CrossRef]

3. Kwak, S.Y.; Yang, J.K.; Choi, H.R.; Park, K.C.; Lee, Y.S.; Kim, Y.B. Synthesis and dual biological effects of hydroxycinnamoyl phenylalanyl/prolyl hydroxamic acid derivatives as tyrosinase inhibitor and antioxidant. Bioorg. Med. Chem. Lett. 2013, 23, 1136-1142. [CrossRef] [PubMed]

4. Giannini, G.; Battistuzzi, G.; Vignola, D. Hydroxamic Acid Based Histone Deacetylase Inhibitors With Confirmed Activity Against The Malaria Parasite. Bioorg. Med. Chem. 2015, 25, 459-461. [CrossRef] [PubMed]

5. Wang, J.; Li, M.S.T.; Gao, A.; Yang, W.; Sheng, L.; Zang, Y.; Li, J.; Liu, H. Design, Synthesis and Biological Evaluation of Thienopyrimidine Hydroxamic Acid Based Derivatives as Structurally Novel Histone Deacetylase (HDAC) Inhibitors. Eur. J. Med. Chem. 2017, 128, 293-299. [CrossRef] [PubMed]

6. De Vreese, R.; D'hooghe, M. Synthesis and Applications of Benzohydroxamic Acid-Based Histone Deacetylase Inhibitors. Eur. J. Med. Chem. 2017, 135, 174-195. [CrossRef]

7. Luckhurst, C.A.; Maillard, M.C.; Aziz, O.; Beaumont, V.; Bürli, R.W.; Breccia, P.; Raphy, G.; Haughan, A.F.; Lamers, M.; Leonard, P.; et al. Development and characterization of a CNS-penetrant benzhydryl hydroxamic acid class IIa histone deacetylase inhibitor. Bioorg. Med. Chem. Lett. 2019, 29, 83-88. [CrossRef]

8. Stranix, B.R.; Wu, J.J.; Milot, G.; Beaulieu, F.; Bouchard, J.E.; Gouveia, K.; Forte, A.; Garde, S.; Wang, Z.; Mouscadet, J.F.; et al. Pyridoxine Hydroxamic Acids As Novel Hiv-Integrase Inhibitors. Bioorg. Med. Chem. Lett. 2016, 26, 1233-1236. [CrossRef]

9. Nam, N.H.; Huong, T.L.; Dung, D.T.M.; Dung, P.T.P.; Oanh, D.T.K.; Quyen, D.; Thao, L.T.; Park, S.H.; Kim, K.R.; Han, B.W.; et al. Novel Isatin-Based Hydroxamic Acids as Histone Deacetylase Inhibitors and Antitumor Agents. Eur. J. Med. Chem. 2013, 70, 477-486. [CrossRef]

10. Li, B.; Zhang, W.; Wu, J.; Zhou, Q.; Wu, S. Synthesis and Biological Activity of Salinomycin-Hydroxamic Acid Conjugates. Bioorg. Med. Chem. Lett. 2017, 27, 1624-1626. [CrossRef]

11. Zhang, W.; Pranolo, Y.; Urbani, M.; Cheng, C.Y. Extraction and Separation of Nickel and Cobalt with Hydroxamic Acids LIX ${ }^{\circledR} 1104$, LIX ${ }^{\circledR} 1104$ SM and The Mixture of LIX ${ }^{\circledR} 1104$ and Versatic 10. Hydrometallurgy 2012, 119, 67-72. [CrossRef]

12. Majewski, M.W.; Cho, S.; Miller, P.A.; Franzblau, S.G.; Miller, M.J. Syntheses and evaluation of substituted aromatic hydroxamates and hydroxamic acids that target mycobacterium tuberculosis. Bioorg. Med. Chem. Lett. 2015, 25, 4933-4936. [CrossRef] [PubMed] 
13. Ai, T.; Qiu, L.; Xie, J.; Geraghty, R.J.; Chen, L. Design and synthesis of an activity-based protein profiling probe derived from cinnamic hydroxamic acid. Bioorg. Med. Chem. 2016, 24, 686-692. [CrossRef] [PubMed]

14. Phillips, O.A.; D’Silva, R.; Bahta, T.O.; Sharaf, L.H.; Udo, E.E.; Benov, L.; Walters, D.E.; Sharaf, L.H. Synthesis and Biological Evaluation of Novel 5-(hydroxamic acid) Methyl Oxazolidinone Derivatives. Eur. J. Med. Chem. 2015, 106, 120-131. [CrossRef] [PubMed]

15. Pacco, A.; Absillis, G.; Binnemans, K.; Parac-Vogt, T.N. Copper (II) 15-Metallacrown-5 Lanthanide (III) Complexes Derived from 1-serine and 1-threonine Hydroxamic Acids. J. Alloys Compd. 2008, 451, $38-41$. [CrossRef]

16. Isha, A.; Suhendra, D.; Yusof, N.A.; Ahmad, M.; Wan Yunus, W.M.Z.; Zainal, Z. Optical Fiber Chemical Sensor for Trace Vanadium(V) Determination Based On Newly Synthesized Palm Based Fatty Hydroxamic Acid Immobilized in Polyvinyl Chloride Membrane. Spectrochim. Acta A 2007, 67, 1398-1402. [CrossRef] [PubMed]

17. Saratale, R.G.; Sivapathan, S.; Saratale, G.D.; Banu, J.R.; Kim, D. Hydroxamic acid mediated heterogeneous Fenton-like catalysts for the efficient removal of Acid Red 88, textile wastewater and their phytotoxicity studies. Ecotoxicol. Environ. Saf. 2019, 167, 385-395. [CrossRef] [PubMed]

18. Gunawan, E.R.; Suhendra, D.; Hidayat, I.; Kurniawati, L. Optimization of Alkyldiethanolamides Synthesis from Terminalia catappa L. Kernel Oil through Enzymatic Reaction. J. Oleo Sci. 2018, 67, 949-955. [CrossRef]

19. Servat, F.; Montet, D.; Pina, M.; Gazly, P.; Arnaud, A.; Ledon, H.; Marcau, L.; Graillie, J. Synthesis of Fatty Hydroxamic Acids Catalyzed by The Lipase of Mucor Meihei. JOACS 1990, 67, 646-649.

20. Suhendra, D.; Haron, M.J.; Silong, S.; Basri, M.; Wan Yunus, W.M.Z. Enzymatic Synthesis of Fatty Hydroxamic Acids from Palm Oil. J. Oleo Sci. 2005, 54, 33-38. [CrossRef]

21. Suhendra, D.; Gunawan, E.R.; Yuanita, E.; Nazili, M. Optimization of Lipase-catalyzed Synthesis of Fatty Hydroxamic acids from Terminalia catappa L. Kernel oil. Orient. J. Chem. 2018, 34, 2370-2377. [CrossRef]

22. Salwanee, S.; Wan Aida, W.M.; Mamot, S.; Maskat, M.Y.; Ibrahim, S. Effects of Enzyme Concentration, Temperature, $\mathrm{pH}$ and Time on the Degree of Hydrolysis of Protein Extract from Viscera of Tuna (Euthynnus affinis) by Using Alcalase. Sains Malaysiana 2013, 42, 279-287.

23. Gunawan, E.R.; Suhendra, D. Four-Factor Response Surface Optimization of the Enzymatic Synthesis of Wax Ester from Palm Kernel Oil. Indones. J. Chem. 2008, 8, 83-90. [CrossRef]

24. Jamil, N.; Che Man, R.; Suhaimi, S.; Shaarani, S.M.; Arshad, Z.I.M.; Mudalip, S.K.A.; Sulaiman, S.Z. Effect of enzyme concentration and temperature on the immobilization of cyclodextrin glucanotransferase (CGTase) on hollow fiber membrane. Mater. Today Proc. 2018, 5, 22036-22042. [CrossRef]

Sample Availability: Samples of the compounds are available from the authors.

(C) 2019 by the authors. Licensee MDPI, Basel, Switzerland. This article is an open access article distributed under the terms and conditions of the Creative Commons Attribution (CC BY) license (http://creativecommons.org/licenses/by/4.0/). 